\title{
IMPROVING BUSINESS PERFORMANCE WITH ISO 9001: A REVIEW OF LITERATURE AND BUSINESS PRACTICE
}

\author{
Mihalj Bakator*, Dragan Ćoćkalo \\ Technical Faculty "Mihajlo Pupin", \\ University of Novi Sad, Serbia
}

\begin{abstract}
:
This paper studies the impact of the ISO 9001 on business performance. In addition, the impact on business performance metrics is also investigated. These metrics are product, and service quality, customer satisfaction, financial performance, and operational performance. In the process of selection, 25 out of 110 papers were chosen for further analysis. The sum of samples is 6605. Therefore, the paper has moderate significance and moderate contribution in the domain of ISO 9001 certification. The key findings of this paper indicated that ISO 9001 certification can improve operational performance, customer satisfaction, financial performance, and overall business performance. However, negative impact of ISO 9001 on the mentioned constructs is also noted. For practical implication, companies may use this systematic review as a tool which may help in decision making regarding ISO 9001 standards certification or overall business performance improvement.
\end{abstract}

\section{Article info:}

Received: December 26, 2017

Correction: February 7, 2018

Accepted: February 12, 2018

\section{Keywords:}

ISO 9001,

impact,

benefits, certification, performance.

\section{INTRODUCTION}

In this paper a systematic literature review is conducted in the domain of ISO 9001 standard benefits, and its overall impact on business performance. Now, Sitki IIkay, \& Aslan, (2012) described that there is no statistical difference between ISO 9001 certified, and non-certified companies regarding business performance. The researched metrics in their study included: profitability, turnover, inventory turnover, waste re-processing costs, capacity utilization rate, defective product ratio, manufacturing lead time, employee satisfaction levels, number of complaints from customers, customer satisfaction levels, number of customers returning products, on-time delivery, response speed of technical services, competitive position, regular training for employees, and cost savings. 
In contrast to the research of Sitki IIlkay, and Aslan (2012), Dick, Heras, and Casadesus (2008), argued that ISO 9001 certification positively influences business performance. The measured metrics in their research were product quality, waste control, cost reduction, competitiveness improvement, sale volume, and profitability. However, it is also noted that good performing companies are more likely to start the certification process. Therefore, these companies have an advantage over companies with low business performance.

Further, Aba, Badar, and Hayden (2016) concluded that ISO 9001 certified companies had better operating performance (consistent volume deliveries, productivity, cost savings, defect product reduction) opposite to non-certified companies. In the same study, it is also noted that significant improvement of operating performance was evident only a year prior to the certification year.

Early research of Simmons, and White (1999) argued that there is no significant difference in operating performance (profit, foreign sales, employee communication, productivity) between ISO 9001 certified and non-certified companies. In contrast, Kafetzopoulos, Psomas, and Gotzamani (2015) noted that ISO 9001 positively affects product quality, and operational performance (productivity, cost savings, waste reduction).

There are many more contradictory research results in the domain of ISO 9001 certification. Therefore, the main objective of this review is to analyse various scientific articles regarding the benefits, and impact of the ISO 9001 standard on business performance. The data is collected in the form of full/ complete scientific papers. The main research questions that this paper addresses are:

1. What are the ISO 9001 standards certification benefits?

2. Is there a substantial difference in business performance between ISO 9001 certified companies and non-certified companies?

In the next section the review methodology will be described. Further, the results are presented. The results include tables of cross-analysed research articles in order to provide a concise preview of the whole review process.

\section{METHODOLOGY}

\section{Literature sources}

There are seven (7) major sources/journals from where the articles are obtained. The papers from these seven journals make more than $60 \%$ of the overall collected literature that was considered for the systematic review. In Table 1, the seven major journals are presented in more detail.

\begin{tabular}{clcc}
\hline & \multicolumn{1}{c}{ Journal name } & ISSN & Publisher \\
\hline 1. & International Journal of Quality \& Reliability Management & $0265-671 X$ & Emerald \\
\hline 2. & International Journal of Operations \& Production Management & $0144-3577$ & Emerald \\
\hline 3. & Journal of Manufacturing Technology Management & $1741-038 X$ & Emerald \\
\hline 4. & Total Quality Management \& Business Excellence & $1478-3363$ & Taylor \& Francis \\
\hline 5. & The TQM Journal & $1754-2731$ & Emerald \\
\hline 6. & The TQM Magazine & $0954-478 X$ & Emerald \\
\hline 7. & International Journal of Productivity and Performance Management & $1741-0401$ & Emerald \\
\hline
\end{tabular}

Table 1 - Seven major sources of literature

Source: Developed for this research 


\section{Literature eligibility criteria}

The earliest published article used in this review, dates from 2000, and the newest article is from 2017. This way, article age bias is avoided. All articles are published in journals with moderate to strong significance. The subjects of the articles addressed one or more of the following constructs:

- ISO 9001 certification

- ISO 9001 certification impact on business performance

- Quality management systems

- Case studies addressing ISO 9001

- ISO 9001 product, and service quality

- ISO 9000 standards

Furthermore, articles in a review process for a certain journal, and articles that are accepted but are not published yet, are not taken into consideration for this review. Predatory journals and predatory conferences are avoided.

\section{Protocol diagram}

The review was conducted according to a structured protocol diagram. The majority of the scientific papers were searched through the Google Scholar service, and KoBSON service. Next, the articles were downloaded, and the duplicates were removed. Afterwards, a screening process was conducted to determine which articles are eligible for the systematic review. The eligible articles were thoroughly analysed. All irrelevant sources were excluded. Figure 1 depicts the protocol diagram used for the literature review process.

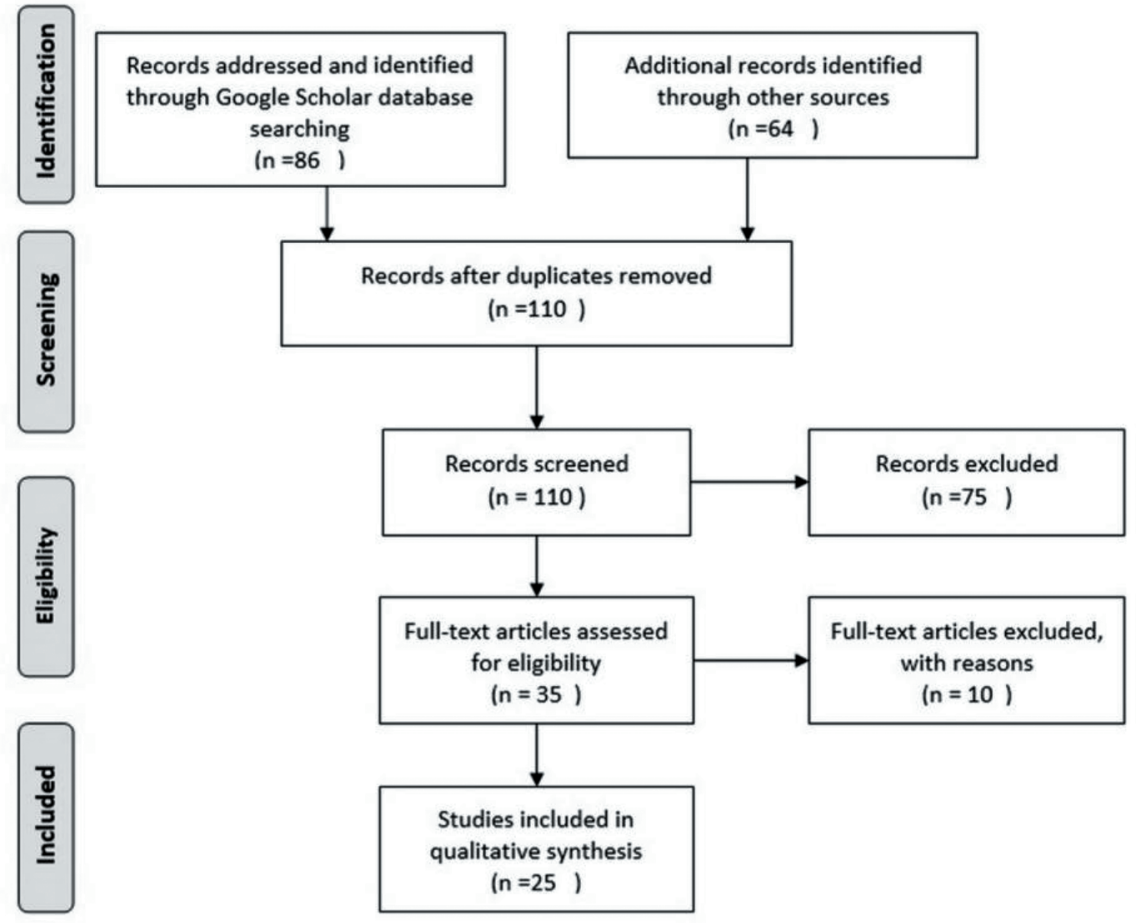

Figure 1 - Protocol diagram (made in accordance with the PRISMA protocol: Moher, Liberati, Tetzlaff, Altman, \& Group, 2010). 


\section{Sample independence}

Few research articles are published by the same authors, with different years of publication, and similar sample sources. For this, each article is analysed, and it is evident that the samples are independent. This independence is ensured through the difference of countries that the research took place in, difference in the industries of the companies, and randomized selection of samples from independent databases (ex. ICAP database used by Psomas, and Kafetzopoulos). There may be a chance that randomized database sampling can result in double counting. However, in this case the consequences are not severe, as the randomization process ensures a low percentage of sample overlapping. In the next section the research results are presented. Afterwards, the paper discusses the findings, and conclusions are drawn.

\section{RESULTS}

\section{Results of individual studies}

After a thorough systematic literature analysis, the main findings of each reviewed article were noted. Author details, sample details, and findings are presented in Table 2.

\begin{tabular}{|c|c|c|c|}
\hline$\#$ & Authors & Sample & Findings \\
\hline R1 & $\begin{array}{l}\text { (Evangelos L. Psomas } \\
\text { \& Kafetzopoulos, } \\
\text { 2014) }\end{array}$ & $\begin{array}{l}140 \text { manufactur- } \\
\text { ing companies in } \\
\text { Greece }\end{array}$ & $\begin{array}{l}\text { ISO } 9001 \text { certified companies significantly outperform } \\
\text { non-certified companies in the domain of product qual- } \\
\text { ity, customer satisfaction, operational performance, and } \\
\text { financial performance. }\end{array}$ \\
\hline R2 & $\begin{array}{l}\text { (Evangelos L. Pso- } \\
\text { mas, Fotopoulos, \& } \\
\text { Kafetzopoulos, 2011) }\end{array}$ & $\begin{array}{l}196 \text { manufactur- } \\
\text { ing companies in } \\
\text { Greece }\end{array}$ & $\begin{array}{l}\text { ISO } 9001 \text { certified companies achieved significant im- } \\
\text { provements regarding product quality. }\end{array}$ \\
\hline R3 & (Terzio & $\begin{array}{l}1500 \text { companies } \\
\text { that have been ISO } \\
9001 \text { certified }\end{array}$ & $\begin{array}{l}\text { ISO } 9001 \text { certification contributed to business perfor- } \\
\text { mance. However, this is the case only when the man- } \\
\text { agers were focused on performance, and not only on } \\
\text { certification. }\end{array}$ \\
\hline R4 & $\begin{array}{c}\text { (Withers \& } \\
\text { Ebrahimpour, 2000) }\end{array}$ & $\begin{array}{l}11 \text { ISO } 9001 \text { certi- } \\
\text { fied companies } \\
\text { from Europe }\end{array}$ & $\begin{array}{l}\text { From } 11 \text { European companies, only } 2 \text { reported very } \\
\text { positive impact on quality. Top management involve- } \\
\text { ment, implementation time, and standard interpreta- } \\
\text { tion were reported as main obstacles. }\end{array}$ \\
\hline R5 & $\begin{array}{l}\text { (Allur, Heras-Saizar- } \\
\text { bitoria, \& Casadesús, } \\
\text { 2014) }\end{array}$ & $\begin{array}{l}110 \text { companies in } \\
\text { Spain, surveyed in } \\
1999 \text { and } 2011\end{array}$ & $\begin{array}{l}\text { Early ISO } 9001 \text { certification that is driven by internal } \\
\text { motives doesn't bring benefits to the company. }\end{array}$ \\
\hline R6 & (Zhang, 2000) & $\begin{array}{l}10 \text { manufacturing } \\
\text { companies in the } \\
\text { Netherlands }\end{array}$ & $\begin{array}{l}\text { TQM has a much better effect on business performance } \\
\text { in opposite to ISO } 9001 .\end{array}$ \\
\hline R7 & $\begin{array}{l}\text { (Zeng, Tian, \& Tam, } \\
\text { 2007) }\end{array}$ & $\begin{array}{l}156 \text { companies } \\
\text { from China }\end{array}$ & $\begin{array}{l}\text { The negative aspects of ISO } 9001 \text { certification are short- } \\
\text { sighted goals, lack of commitment from certifying bodies, } \\
\text { and excessive competition between certifying bodies. }\end{array}$ \\
\hline
\end{tabular}




\begin{tabular}{|c|c|c|c|}
\hline R8 & $\begin{array}{l}\text { (Feng, Terziovski, \& } \\
\text { Samson, 2007) }\end{array}$ & $\begin{array}{l}613 \text { ISO } 9001 \\
\text { certified compa- } \\
\text { nies from Australia } \\
\text { and New Zealand }\end{array}$ & $\begin{array}{l}\text { A strong positive relationship was found between ISO } \\
9001 \text { certification and operational performance. In } \\
\text { contrast, there was a positive, but insignificant relation- } \\
\text { ship between business performance and ISO } 9001 \text { cer- } \\
\text { tification. }\end{array}$ \\
\hline R9 & $\begin{array}{l}\text { (Tzelepis, Tsekouras, } \\
\text { Skuras, \& Dimara, } \\
\text { 2006) }\end{array}$ & $\begin{array}{l}1572 \text { manufactur- } \\
\text { ing companies } \\
\text { from Greece }\end{array}$ & $\begin{array}{l}\text { ISO } 9001 \text { certification is superior to non-certified com- } \\
\text { panies regarding production inefficiency. }\end{array}$ \\
\hline R10 & $\begin{array}{l}\text { (Paulo Sampaio, } \\
\text { Saraiva, \& Monteiro, } \\
\text { 2012) }\end{array}$ & $\begin{array}{l}6 \text { companies (not } \\
\text { specified) }\end{array}$ & $\begin{array}{l}\text { The findings argued that it is not unanimous that ISO } \\
9001 \text { certified companies would have lower financial } \\
\text { performance if they had not implemented the ISO } 9001 \\
\text { certificate. }\end{array}$ \\
\hline R11 & $\begin{array}{l}\text { (Paulo Sampaio, } \\
\text { Saraiva, \& Guimarães } \\
\text { Rodrigues, 2009) }\end{array}$ & $\begin{array}{l}\text { Data from across } \\
\text { countries was } \\
\text { collected including } \\
\text { the top ten coun- } \\
\text { tries in ISO } 9001 \\
\text { certificate growth: } \\
\text { China, Italy, Japan, } \\
\text { Spain, UK, USA, } \\
\text { Germany, India, } \\
\text { France, Australia }\end{array}$ & $\begin{array}{l}\text { Companies achieve benefits if the certification is driven } \\
\text { by internal motives. There is a positive impact on busi- } \\
\text { ness performance. Lack of top management involvement } \\
\text { in the certification process is considered as a big obstacle. }\end{array}$ \\
\hline $\mathrm{R} 12$ & $\begin{array}{l}\text { (Quazi \& Jacobs, } \\
\text { 2004) }\end{array}$ & $\begin{array}{l}33 \text { ISO } 9001 \text { certi- } \\
\text { fied companies } \\
\text { from Singapore }\end{array}$ & $\begin{array}{l}\text { ISO } 9001 \text { certified companies reported higher business } \\
\text { performance. }\end{array}$ \\
\hline R13 & $\begin{array}{l}\text { (Quazi, Hong, \& } \\
\text { Meng, 2010) }\end{array}$ & $\begin{array}{l}93 \text { service, and } \\
\text { construction } \\
\text { companies from } \\
\text { Singapore, cross- } \\
\text { referenced with } \\
346 \text { companies } \\
\text { from Mexico, } \\
\text { China, India, and } \\
\text { USA }\end{array}$ & $\begin{array}{l}\text { The findings suggest that ISO } 9001 \text { certification doesn't } \\
\text { have an impact on quality results. }\end{array}$ \\
\hline R14 & $\begin{array}{l}\text { (Honore, Yaya, } \\
\text { Marimon, \& } \\
\text { Casadesus, 2013) }\end{array}$ & $\begin{array}{l}123 \text { online banking } \\
\text { customers }\end{array}$ & $\begin{array}{l}\text { Results indicate that ISO } 9001 \text { didn't have an impact on } \\
\text { customer satisfaction. However, the customer loyalty } \\
\text { and customer satisfaction relationship showed a stagger- } \\
\text { ing } 47 \text { percent of improvement. }\end{array}$ \\
\hline R15 & $\begin{array}{l}\text { (Evangelos L. Pso- } \\
\text { mas, Pantouvakis, \& } \\
\text { Kafetzopoulos, 2013) }\end{array}$ & $\begin{array}{l}100 \text { ISO certified } \\
\text { companies from } \\
\text { Greece }\end{array}$ & $\begin{array}{l}\text { The results indicate that product, and service quality, } \\
\text { and operational performance were significantly influ- } \\
\text { enced by ISO } 9001 \text {. }\end{array}$ \\
\hline R16 & $\begin{array}{l}\text { (Poksinska, Eklund, } \\
\text { \& Dahlgaard, 2006) }\end{array}$ & $\begin{array}{l}3 \text { case studies of } \\
\text { small organiza- } \\
\text { tions }\end{array}$ & $\begin{array}{l}\text { After certification, minimum change was experienced, } \\
\text { as the standard was perceived as a tool for handling } \\
\text { documentation. There were external benefits due to the } \\
\text { certificate. However, no internal benefits were achieved. }\end{array}$ \\
\hline R17 & $\begin{array}{l}\text { (Ochieng, Muturi, \& } \\
\quad \text { Njihia, 2015) }\end{array}$ & $\begin{array}{l}20 \text { organizations } \\
\text { from East Africa }\end{array}$ & $\begin{array}{l}\text { Findings argued that ISO } 9001 \text { certified companies had } \\
\text { higher performance regarding net assets in opposite to } \\
\text { non-certified companies. However, there was no signif- } \\
\text { cant difference in profit and revenue. }\end{array}$ \\
\hline
\end{tabular}




\begin{tabular}{|c|c|c|c|}
\hline $\mathrm{R} 18$ & $\begin{array}{l}\text { (Morris, Crawford, } \\
\text { Carter, \& Mazotta, } \\
\text { 2000) }\end{array}$ & 15 organizations & $\begin{array}{l}\text { The findings indicate that the ISO } 9001 \text { certificate doesn't } \\
\text { necessarily provide effective performance improvement. }\end{array}$ \\
\hline R19 & $\begin{array}{l}\text { (Martínez-Costa, } \\
\text { Martinez, \& Martín- } \\
\text { ez-Lorente, 2007) }\end{array}$ & 713 companies & $\begin{array}{l}\text { The paper's findings suggest that ISO } 9001 \text { can reduce } \\
\text { benefits, and profitability. }\end{array}$ \\
\hline $\mathrm{R} 20$ & $\begin{array}{l}\text { (Kim, Kumar, \& } \\
\text { Kumar, 2011) }\end{array}$ & $\begin{array}{l}\text { Systematic } \\
\text { review }\end{array}$ & $\begin{array}{l}\text { It is argued that the various internal and external motiva- } \\
\text { tors for certification play an important role in achieving } \\
\text { higher business performance. Therefore, merely adopting } \\
\text { the ISO } 9001 \text { certificate, won't bring benefits, if other or- } \\
\text { ganizational factors are not included. }\end{array}$ \\
\hline R21 & (Jang \& Lin, 2008) & $\begin{array}{l}441 \text { ISO } 9001 \\
\text { certified } \\
\text { companies }\end{array}$ & $\begin{array}{l}\text { ISO } 9001 \text { certification improved operational perfor- } \\
\text { mance, indirectly improved market performance, and } \\
\text { business performance. }\end{array}$ \\
\hline $\mathrm{R} 22$ & $\begin{array}{l}\text { (K. D. Gotzamani, } \\
\text { Tsiotras, Nicolaou, } \\
\text { Nicolaides, \& Hadji- } \\
\text { adamou, 2007) }\end{array}$ & $\begin{array}{l}352 \text { ISO } 9001 \\
\text { certified compa- } \\
\text { nies from Cyprus }\end{array}$ & $\begin{array}{l}\text { The main conclusion is that ISO } 9001 \text { certified compa- } \\
\text { nies improved process management performance. }\end{array}$ \\
\hline $\mathrm{R} 23$ & (K. Gotzamani, 2010) & $\begin{array}{l}87 \text { SMEs from } \\
\text { Greece }\end{array}$ & $\begin{array}{l}\text { ISO } 9001 \text { standard contributed to higher product qual- } \\
\text { ity, and improvement of processes. }\end{array}$ \\
\hline $\mathrm{R} 24$ & $\begin{array}{l}\text { (Chatzoglou, Chat- } \\
\text { zoudes, \& Kipraios, } \\
\text { 2015) }\end{array}$ & $\begin{array}{l}168 \text { companies } \\
\text { from Greece }\end{array}$ & $\begin{array}{l}\text { The study noted that ISO } 9001 \text { implementation im- } \\
\text { proved financial performance, quality awareness, op- } \\
\text { eration execution, market share, customer satisfaction, } \\
\text { and sales revenue. }\end{array}$ \\
\hline $\mathrm{R} 25$ & $\begin{array}{l}\text { (Cândido, Coelho, \& } \\
\text { Peixinho, 2016) }\end{array}$ & $\begin{array}{l}143 \text { Portuguese } \\
\text { companies that } \\
\text { lost their ISO } 9001 \\
\text { certification and } \\
\text { companies that } \\
\text { maintained the } \\
\text { certificate }\end{array}$ & $\begin{array}{l}\text { Findings indicated that there is no significant difference } \\
\text { regarding financial performance, between companies } \\
\text { who lost their ISO } 9001 \text { certification, and certified com- } \\
\text { panies. }\end{array}$ \\
\hline
\end{tabular}

Table 2 - Authors, sample details, and findings of reviewed articles

Source: Developed for this research

\section{Synthesis of results}

For this systematic review, twenty-four (24) research articles, and one (1) review article were investigated. The total number of companies of 6605 is significant enough for a systematic review. The sample details are presented in Table 3. 


\begin{tabular}{clcc}
\hline$\#$ & \multicolumn{1}{c}{ Country } & $\begin{array}{c}\text { Sample size from positive } \\
\text { research findings }\end{array}$ & $\begin{array}{c}\text { Sample size where negative or } \\
\text { no benefits of ISO 9001 were } \\
\text { reported }\end{array}$ \\
\hline 1. & Greece & 2163 & 100 \\
\hline 2. & Global (not specified) & 441 & 2360 \\
\hline 3. & Europe (not specified) & 4 & 7 \\
\hline 4. & Spain & 0 & 110 \\
\hline 5. & Netherlands & 0 & 10 \\
\hline 6. & China & 0 & 156 \\
\hline 7. & Australia, New Zealand & 613 & 0 \\
\hline 8. & Singapore & 33 & 93 \\
\hline 9. & East-Africa & 0 & 20 \\
\hline 10. & Cyprus & 352 & 143 \\
\hline 11. & Portugal & 0 & $\mathbf{2 9 9 9}$ \\
\hline TOTAL & & 3606 & 0 \\
\hline
\end{tabular}

Table 3 - Samples categorized by country, and findings

Source: Developed for this research

According to Table 3, the sum of samples, where ISO 9001 certification brought benefits to the company, is 3606. The number of samples where the research showed that there are no benefits of

ISO 9001 certification is 2999. Next, on Figure 2, the percentage of positive and negative/no impact research results are presented. In addition, the five factors of improvement are shown, along with the research articles and the sample size details.

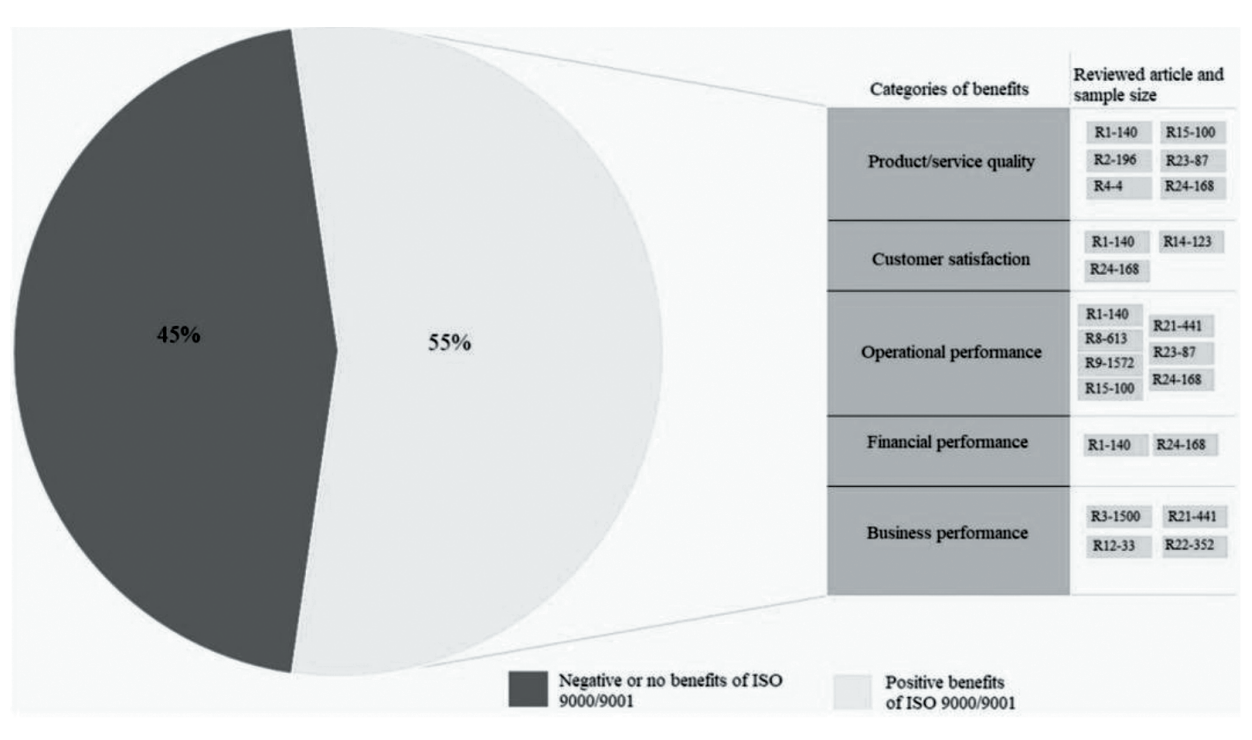

Figure 2 - Percentage of positive, and negative/no benefits of ISO 9001 certification with detailed factors, and article details (Source: Developed for this research) 
Figure 2 shows that 55 percent of the total sample size, experienced benefits from ISO 9001 certification. Product/service quality was recorded in six reviewed papers, operational performance in seven, customer satisfaction in three, business performance in four, and financial performance increase in two reviewed papers. In the next section the results are discussed, and conclusions are drawn.

\section{DISCUSSION AND CONCLUSION}

In their meta-analysis Psomas, and Fotopoulos (2009) noted that the ISO 9001:2000 certificate generally contributed to business performance, and operational performance. Complementary to their meta-analysis, this systematic review obtained similar results. Next, Casadesús, and Karapetrovic (2005) investigated the possible long-term benefits, and the negative impact of ISO 9001 certification. They noted that the ISO 9001 standard is limited regarding implementation time, and overall benefits. In addition, Ataseven, Prajogo, and Nair (2014) discussed that ISO 9001 certification improves business performance through improved processes.

The ISO 9001:2015 standard brought improvements over the previous ISO 9001:2008 standard. These improvements include greater leadership engagement, simplified language and terms, structured organizational risks and opportunities, user friendly documentation, and the supply chain management is more effectively defined (International Organization for Standardization, 2015). The newer ISO 9001:2015 standard is more risk oriented in opposite to previous editions. It holds accountable the top management for risk management (Rybski, Jochem, \& Homma, 2017). Similarly, Sari, Wibisono, Wahyudi, and Lio (2017) noted that ISO 9001:2015 has a risk-based approach. Therefore, organizations can formulate their implementation strategies in such a manner that the negative impact of ISO 9001:2015 certification is minimal.

Furthermore, the findings answered the previously defined research questions. These are the following:

\section{What are the ISO 9001 standards certification benefits?}

The benefits may include higher product, and service quality, strong improvement in operational performance, moderate improvement in financial performance, moderate improvement in customer satisfaction, improved overall business performance.

\section{Is there a substantial difference in business performance between ISO 9001 certified compa- nies and non-certified companies?}

The results of this review paper suggested that in some findings there is no difference between certified and non-certified companies regarding business performance. In addition, some articles noted that there are no benefits before, and after ISO 9001 certification. Other research findings indicated that there were mild external benefits regarding the certificate itself, while minimal internal improvement was reported. There are many factors that influence the results of ISO 9001 certification. These factors may include type of organization, size, industry, market, customers, and organizational culture.

Furthermore, the contributions of this paper are moderate. Qualitative insight is obtained in the domain of ISO 9001 certification. The reviewed articles provided a large sum of samples, and the size of the samples further strengthened the contribution of the final results.

The main limitation of this paper is the non-analytical approach regarding the quantitative results of individual research papers. However, the qualitative data obtained from the analysed literature gives a insight when it comes to the impact of ISO 9001 certification. 
Furthermore, this review paper concisely shows the findings of 25 scientific articles. According to the synthesis of the results, there is a chance that ISO 9001 certification brings benefits in $50 \%$ of all cases. It is important to note, that this represents only the sample size of individual research articles. The exact number of companies that reported positive or negative impact of ISO 9001 certification is not presented. In the majority, companies reported that they experienced improved product/service quality, and operational performance. Moderate improvement was noted in the domain of customer satisfaction, financial performance, and overall business performance.

As mentioned before, the significance of these percentages must be taken with appropriate reservation. The samples are viewed as a whole. This excludes the number of companies that reported benefits, when the majority responded negatively, and vice-versa. Practical implications of this systematic review may include improved decision making of managers regarding ISO 9001 certification.

For future research, other factors should be included in the review. It is recommended to address a larger body of literature, and define the development and certification of ISO 9001 within defined time frames including a minimum time span of 30 years, where various versions of ISO 9001 standards are analysed.

\section{REFERENCES}

Aba, E. K., Badar, M. A., \& Hayden, M. A. (2016). Impact of ISO 9001 certification on firms financial operating performance. International Journal of Quality \& Reliability Management, 33(1), 78-89. DOI: 10.1108/ ijqrm-02-2014-0021

Allur, E., Heras-Saizarbitoria, I., \& Casadesus, M. (2014). Internalization of ISO 9001: a longitudinal survey. Industrial Management \& Data Systems, 114(6), 872-885. DOI: 10.1108/IMDS-01-2014-0013

Ataseven, C., Prajogo, D. I., \& Nair, A. (2014). ISO 9000 internalization and organizational commitmentimplications for process improvement and operational performance. IEEE Transactions on Engineering Management, 61(1), 5-17.

Candido, C. J. F., Coelho, L. M. S., \& Peixinho, R. M. T. (2016). The financial impact of a withdrawn ISO 9001 certificate. International Journal of Operations \& Production Management, 36(1), 23-41. DOI: 10.1108/ IJOPM-11-2014-0540

Casadesus, M., \& Karapetrovic, S. (2005). Has ISO 9000 lost some of its lustre? A longitudinal impact study. International Journal of Operations \& Production Management, 25(6), 580-596. DOI: 10.1108/01443570510599737

Chatzoglou, P., Chatzoudes, D., \& Kipraios, N. (2015). The impact of ISO 9000 certification on firms' financial performance. International Journal of Operations \& Production Management Decision, 35(1), 145-174. DOI: 10.1108/IJOPM-07-2012-0387

Dick, G. P., Heras, I., \& Casadesús, M. (2008). Shedding light on causation between ISO 9001 and improved business performance. International Journal of Operations \& Production Management, 28(7), 687-708. DOI: $10.1108 / 01443570810881811$

Feng, M., Terziovski, M., \& Samson, D. (2007). Relationship of ISO 9001: 2000 quality system certification with operational and business performance: A survey in Australia and New Zealand-based manufacturing and service companies. Journal of Manufacturing Technology Management, 19(1), 22-37. DOI: 10.1108/01409170410784365

Gotzamani, K. (2010). Results of an empirical investigation on the anticipated improvement areas of the ISO 9001:2000 standard. Total Quality Management \& Business Excellence, 21(6), 687-704. DOI:10.1080/14783 363.2010.483101

Gotzamani, K. D., Tsiotras, G. D., Nicolaou, M., Nicolaides, A., \& Hadjiadamou, V. (2007). The contribution to excellence of ISO 9001: the case of certified organisations in Cyprus. The TQM Magazine, 19(5), 388-402. DOI: $10.1108 / 09544780710817838$ 
Honore, L., Yaya, P., Marimon, F., \& Casadesus, M. (2013). Can ISO 9001 improve service recovery? Industrial Management \& Data Systems, 113(8), 1206-1221. DOI: 10.1108/IMDS-03-2013-0150

International Organization for Standardization (2015). ISO 9001: Moving from ISO 9001:2008 to ISO 9001:2015. Geneva, Switzerland: ISO Central Secretariat Chemin de Blandonnet.

Jang, W.-Y., \& Lin, C.-I. (2008). An integrated framework for ISO 9000 motivation, depth of ISO implementation and firm performance. Journal of Manufacturing Technology Management, 19(2), 194-216. DOI: $10.1108 / 17410380810847918$

Kafetzopoulos, D. P., Psomas, E. L., \& Gotzamani, K. D. (2015). The impact of quality management systems on the performance of manufacturing firms. International Journal of Quality \& Reliability Management, 32(4), 381-399. DOI: 10.1108/IJQRM-11-2013-0186

Kim, D. Y., Kumar, V., \& Kumar, U. (2011). A performance realization framework for implementing ISO 9000. International Journal of Quality \& Reliability Management, 28(4), 383-404. DOI: 10.1108/02656711111121807

Martinez-Costa, M., Martinez, V., \& Martínez-Lorente, Á. R. (2007). A triple analysis of ISO 9000 effects on company performance. International Journal of Productivity and Performance Management, 56(5/6), 484-499. DOI: $10.1108 / 17410400710757150$

Moher, D., Liberati, A., Tetzlaff, J., Altman, D. G., \& Group, P. (2010). Preferred reporting items for systematic reviews and meta-analyses: the PRISMA statement. International Journal of Surgery, 8(5), 336-341.

Morris, A., Crawford, J., Carter, D., \& Mazotta, F. (2000). Management decisions for effective ISO 9000 accreditation. Management Decision, 38(3), 182-193. DOI: 10.1108/EUM0000000005346

Ochieng, J., Muturi, D., \& Njihia, S. N. (2015). The impact of ISO 9001 implementation on organizational performance in Kenya. The TQM Journal, 27(6), 761-771. DOI: 10.1108/TQM-06-2015-0071

Poksinska, B., Eklund, J. A. E., \& Dahlgaard, J. J. (2006). ISO 9001:2000 in small organisations. International Journal of Quality \& Reliability Management, 23(5), 490-512. DOI: 10.1108/02656710610664578

Psomas, E. L., \& Fotopoulos, C. V. (2009). A meta analysis of ISO 9001: 2000 research-findings and future research proposals. International Journal of Quality and Service Sciences, 1(2), 128-144. DOI: $10.1108 / 17566690910971418$

Psomas, E. L., Fotopoulos, C. V., \& Kafetzopoulos, D. P. (2011). Core process management practices, quality tools and quality improvement in ISO 9001 certified manufacturing companies. Business Process Management Journal, 17(3), 437-460. DOI: 10.1108/14637151111136360

Psomas, E. L., \& Kafetzopoulos, D. P. (2014). Performance measures of ISO 9001 certified and noncertified manufacturing companies. Benchmarking: An International Journal, 21(5), 756-774. DOI: 10.1108/BIJ-04-2012-0028

Psomas, E. L., Pantouvakis, A., \& Kafetzopoulos, D. P. (2013). The impact of ISO 9001 effectiveness on the performance of service companies. Managing Service Quality: An International Journal of Advertising, 23(2), 149-164. DOI: $10.1108 / 09604521311303426$

Rybski, C., Jochem, R., \& Homma, L. (2017). Empirical study on status of preparation for ISO 9001:2015. Total Quality Management \& Business Excellence, 1076-1089.

Sari, Y., Wibisono, E., Wahyudi, R., \& Lio, Y. (2017). From ISO 9001: 2008 to ISO 9001: 2015: Significant changes and their impacts to aspiring organizations. Paper presented at the IOP Conference Series: Materials Science and Engineering, 273(1), 12-21

Quazi, H. A., Hong, C. W., \& Meng, C. T. (2010). Impact of ISO 9000 certification on quality management practices: A comparative study. Total Quality Management \& Business Excellence, 13(1), 53-67. DOI: $10.1080 / 09544120120098564$

Quazi, H. A., \& Jacobs, R. L. (2004). Impact of ISO 9000 certification on training and development activities. International Journal of Quality \& Reliability Management, 21(5), 497-517. DOI: 10.1108/02656710410536545

Sampaio, P., Saraiva, P., \& Guimarães Rodrigues, A. (2009). ISO 9001 certification research: questions, answers and approaches. International Journal of Quality \& Reliability Management, 26(1), 38-58. DOI: 10.1108/02656710910924161 
Sampaio, P., Saraiva, P., \& Monteiro, A. (2012). ISO 9001 certification pay-off: myth versus reality. International Journal of Quality \& Reliability Management, 29(8), 891-914. DOI: 10.1108/02656711211270351

Simmons, B. L., \& White, M. A. (1999). The Relationship Between ISO 9000 and Business Performance: Does Registration Really Matter? Journal of Managerial Issues, 11(3), 330-343.

Sttki İlkay, M., \& Aslan, E. (2012). The effect of the ISO 9001 quality management system on the performance of SMEs. International Journal of Quality \& Reliability Management, 29(7), 753-778. DOI:10.1108/02656711211258517

Terziovski, M., Damien Power, \& Sohal, A. S. (2003). The longitudinal effects of the ISO 9000 certification process on business performance. European Journal of Operational Research, 146(3), 580-595.

Tzelepis, D., Tsekouras, K., Skuras, D., \& Dimara, E. (2006). The effects of ISO 9001 on firms' productive efficiency. International Journal of Operations \& Production Management, 26(10), 1146-1165. DOI: $10.1108 / 01443570610691111$

Withers, B., \& Ebrahimpour, M. (2000). Does ISO 9000 certification affect the dimensions of quality used for competitive advantage? European Management Journal, 18(4), 431-443.

Zeng, S. X., Tian, P., \& Tam, C. M. (2007). Overcoming barriers to sustainable implementation of the ISO 9001 system. Managerial Auditing Journal, 22(3), 244-254. DOI: 10.1108/02686900710733125

Zhang, Z. (2000). Developing a model of quality management methods and evaluating their effects on business performance. Total Quality Management \& Business Excellence 11(1), 129-137. DOI: 10.1080/0954412007071

\section{UNAPREĐENJE POSLOVNIH PERFORMANSI UVOĐENJEM STANDARDA ISO 9001: PREGLED LITERATURE I POSLOVNE PRAKSE}

\section{Rezime:}

Ovaj rad proučava uticaj standarda ISO 9001 na poslovne performanse. Pored toga, istražuje se i uticaj na merenje performansi poslovanja. Kao merne jedinice uzeti su proizvod, kvalitet usluga, zadovoljstvo kupaca, finansijski učinak i operativni učinak. U procesu selekcije, 25 od 110 radova je izabrano za dalju analizu. Ukupno je analizirano 6605 uzoraka. Stoga rad ima umereni značaj i umereni doprinos u domenu sertifikacije ISO 9001. Ključni nalazi ovog rada pokazali su da sertifikacija ISO 9001 može poboljšati operativne performanse, zadovoljstvo kupaca, finansijske performanse i ukupne poslovne performanse. Međutim, primećen je i negativan uticaj ISO 9001 na pomenute konstrukcije. Zarad praktične implikacije, kompanije mogu koristiti ovaj sistematski pregled kao alat koji može pomoći pri donošenju odluka u vezi sa ISO 9001 sertifikacijom ili poboljšanjem ukupnog poslovanja.

\section{Ključne reči:}

ISO 9001, uticaj, benfiti, sertifikacija, performanse 